\title{
Properties of the recycled base course with respect to the road binder type
}

\author{
Marek Iwański, Przemysław Buczyński \\ Department of Transportation Engineering, Faculty of Civil Engineering and Architekture \\ Kielce University of Technology, Al. 1000-lecia P.P. 7, 25-314 Kielce
}

\begin{abstract}
This paper presents the results from the tests performed on the recycled base mixes manufactured in cold deep recycling technology with bitumen emulsion and different types of binding agent. Portland cement denoted as CEM I 32.5, lime and the blends of both were used. The mineral mix design was based on the recycled material derived from the local road renovation. The material consisted of recycled bituminous layers and base unbound aggregate. For the purpose of evaluating an influence of the binding agents, the tests were to determine indirect tensile strength (ITS), indirect tensile modulus ( $\mathrm{Sm}$ ) at specific temperatures of $0{ }^{\circ} \mathrm{C}, 10^{\circ} \mathrm{C}$ and $20^{\circ} \mathrm{C}$ and water and frost resistance of the recycled base mixes. The results obtained from the tests indicated that the impact of the tested binders on the properties of recycled base varies. In addition, a beneficial influence was observed of a little amount of lime in binder blends on water and frost resistance of the recycled base. The paper provides a preliminary assessment of the amounts recommended for application.
\end{abstract}

Keywords: Deep cold recycling; binding agents; wather resistance; bitumen emulsion; cement and lime.

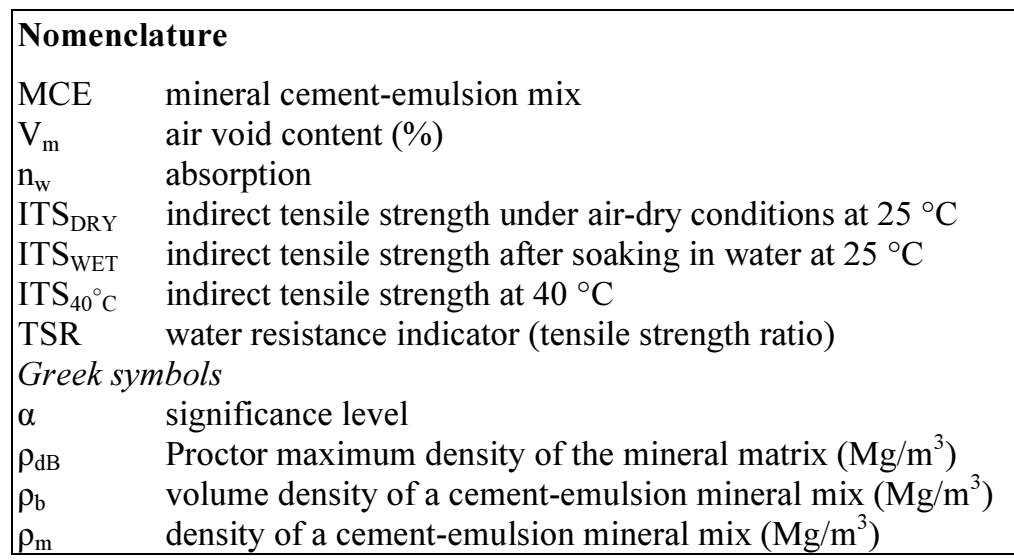

\section{Introduction}

The technology of cold recycling with bitumen emulsion is used for road rehabilitation and strengthening of the loadcarrying capacity of modernised roads. In the process of reconstruction, the damaged structural layers of the pavement are transformed into load-carrying base courses [1], [2]. The advantage of this technology lies in the possible use of lower quality materials provided that the requirements laid down in [3] are met. One of the requirements is that the highest quality Portland cement $325 \mathrm{R}(\mathrm{N})$ or $42.5 \mathrm{R}(\mathrm{N})$ must be applied with no additions. The performance of different class cements and quicklime with respect to emulsified bitumen recycling has been analysed by many researchers [3-9].

Accordingly, the properties of the recycled base with bitumen emulsion have to be determined in terms of the binders used. Also, the potential they have as a replacement for a high quality Portland cement has to be studied.

Corresponding author: Przemysław Buczyński. E-mail address: p.buczynski@tu.kielce.pl

http://dx.doi.org/10.3846/enviro.2014.156

(C) 2014 The Authors. Published by VGTU Press. This is an open-access article distributed under the terms of the Creative Commons Attribution License, which permits unrestricted use, distribution, and reproduction in any medium, provided the original author and source are credited. 


\section{Subject of the study}

The subject of the study was the effect of different binders and their blends (cement, lime and fly ash) on the properties of the mineral cement-emulsion mix MCE, manufactured in the cold recycling technology [3]. The recycled base mix was designed for the fatigue life of 5500000 ESAL standard $100 \mathrm{kN}$ axle load applications/20 years or to KR4 category (medium/heavy traffic) according to the Polish standard [10]. One mixture was prepared and the binder at varying contents was added (MIX-1 to MIX-7).

\subsection{Mineral mix design}

The base course mix design assumed using the existing subgrade soil (fine sand $0 / 2$ with $8.6 \%$ silt clay fraction), aggregate with continuous grading of $0 / 32$ and reclaimed asphalt. This combination allowed a simulation of the deep cold in-situ recycling process. The sand used corresponded to the soil subbase with a $\mathrm{CBR}>10 \%$ and the aggregate $0 / 32$ corresponded to the aggregate base. The reclaimed asphalt was derived from the damaged bituminous structural layers. The mineral cementemulsion mix contained 3\% cationic slow setting bitumen emulsion C60B10 ZM/R. The type of the emulsion was chosen to the Annex to the Polish standard [11]. Table 1 summarizes the basic physical parameters of the bitumen emulsion.

Table 1. Physical properties of asphalt emulsions

\begin{tabular}{lll}
\hline Properties & Units & Emulsion C60B10 ZM/R \\
\hline Binder content & $\%(\mathrm{~m} / \mathrm{m})$ & 60 \\
Mixing stability with cement & $\mathrm{g}$ & 1.0 \\
$0.5 \mathrm{~mm}$ sieve residue & $\%(\mathrm{~m} / \mathrm{m})$ & 0.04 \\
Efflux time $\varnothing 2 \mathrm{~mm}$ at $40 \mathrm{OC}$ & $\mathrm{s}$ & 32 \\
Adhesion to aggregate & $\%$ & 85 \\
Recycled asphalt penetration & $0.1 \mathrm{~mm}$ & 107 \\
Recycled asphalt softening temperature & OC & 45 \\
\hline
\end{tabular}

The road binders in the recycled base were added at a $2.5 \%$ level. Table 2 shows percentages of mineral components used. The grading curve for the designed mix is presented in Fig. 1.

Table 2. Mineral mix components

\begin{tabular}{ll}
\hline Component & Content $(\%)$ \\
\hline Reclaimed asphalt & 48.5 \\
Aggregate 0/32 & 25.2 \\
Sand 0/2 & 20.8 \\
Emulsion C60B10ZM/R & 3.0 \\
Binder (1-7) & 2.5 \\
\hline
\end{tabular}

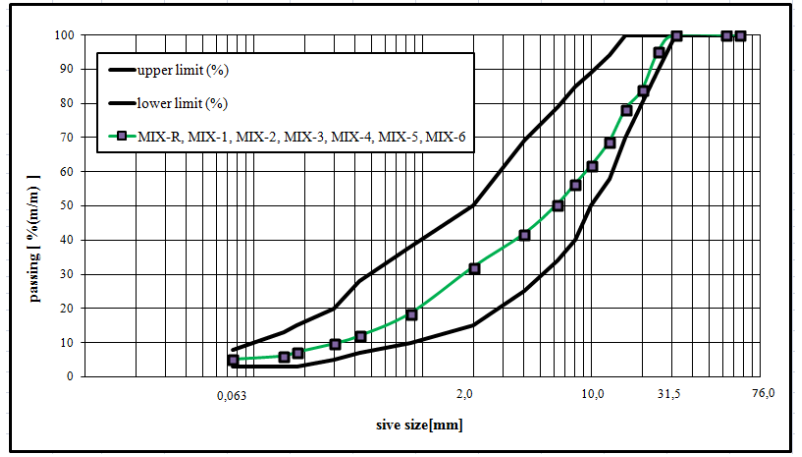

Fig. 1. Design grading curve

The mineral mix was optimized in such a way that the grading curve lies the central part of the good grading range, in between given limits, providing the correct mineral matrix. Obtaining a greater silt clay fraction (less than $0.063 \mathrm{~mm}$ ) was an additional condition to meet. Its content obtained in the design process was $6.1 \%$.

\subsection{Binders}

The binders were chosen from among the most common binding agents used in road and building construction (lime, cement) and a mixture of those agents in different proportions with or without an addition of dusts from lime and cement kilns. To determine the impact of hydraulic binders on the properties of the recycled mix, seven different road binders were used, as in Table 3. 
Table 3. Binders used in the recycled base

\begin{tabular}{llll}
\hline Binder symbol & Description & Mix denotation & $\begin{array}{l}\text { Specific surface area }- \\
\text { Blaine value }(\mathrm{cm} 2 / \mathrm{g})\end{array}$ \\
\hline "R" & $100 \%$ CEM I 32.5R & MIX-1 & 3490 \\
$" 1 "$ & MIX-2 & 4570 \\
$" 2 "$ & $100 \%$ CEM II/B-V 32.5R & MIX-3 & 4210 \\
$" 3 "$ & $50 \%$ CEM I 32.5R + 50\% dusts from lime kilns & MIX-4 & 5120 \\
$" 4 "$ & $50 \%$ CEM I 42.5R + 50\% dusts from cement kilns (CKD) & MIX-5 & 6420 \\
$" 5 "$ & $25 \%$ CEM I 32.5R + 75\% quicklime CaO & MIX-6 & 5760 \\
"6" & $50 \%$ CEM I 32.5R + 50\% quicklime CaO & MIX-7 & 6510 \\
\hline
\end{tabular}

The choice of the binders was dictated by their availability and common use. Technical requirements [3] forced the use of Portland cement CEM I 32.5R. The mineral cement-emulsion mix prepared to [3] is denoted as reference mix, MIX-R. Multi-component Portland cement with an addition of 21-355 fly ash [12] was used due to its availability and a high demand. All Polish cement plants produce this type of cement (CEM II/B-V 32.5R).

Quicklime was used to ensure coagulation and ion exchange. When the mineral material contains clay parts, quicklime will reduce their negative influence on the properties of the recycled base. The deep cold recycling technique allows using mineral materials with lower parameters [3], [13], [14] and clay parts. Therefore it is necessary to determine the impact of this binder type on the properties of the base course in the cold recycling technique with bitumen emulsion.

Dusts that derive from the cement (CKD) and limekilns are a waste product of cement or lime production. Their utilization is a challenging issue, addressed by many researchers [15-19] dealing with sewage sludge stabilisation. Due to $30-40 \% \mathrm{CaO}$ content [18], [19], sewage sludge is highly reactive. Too much $\mathrm{CaO}$ in the composition of the binder may delay hydration, cause volume change, and ultimately damage the hardened mix [20].

\section{Methodology, results and analysis}

The aim of this study was to evaluate the impact of hydraulic binders on changes in physical and mechanical properties of the recycled base mix manufactured in the deep cold technique with bitumen emulsion, and to determine its resistance to water (TSR) [3], [13], [21].

To evaluate the impact of the binders on the properties of the mixes, determining the compaction level and air void content (Marshall test) was necessary. The compaction ratio should be $\geq 98 \%$ [3], [13] and the air void content should be in the range $5-12 \%$ [3]. Ensuring the same level of the air void content in all the recycled base mixes allows obtaining the results that are not burdened with the impact of this parameter variation.

The density of the mineral cement emulsion mix was found with the Proctor method [22], determining the maximum mineral matrix density $\rho_{\mathrm{dB}}$. To find the air void content $\mathrm{V}_{\mathrm{m}}$, first the density of the mix $\rho_{\mathrm{m}}$ was determined [23] and then the void free bulk density $\rho b$ was established for the mineral mix with different types of binder [24]. The results of determining the compaction ratio and the air void content are summarized in Table 4.

Table 4. Compaction ratio values

\begin{tabular}{llllll}
\hline Mix number & $\begin{array}{l}\text { Proctor density } \rho \mathrm{dB} \\
(\mathrm{Mg} / \mathrm{m} 3)\end{array}$ & $\begin{array}{l}\text { Void free bulk density } \\
\rho b\left(\mathrm{Mg} / \mathrm{m}^{3}\right)\end{array}$ & $\begin{array}{l}\text { Density } \rho \mathrm{m} \\
\left(\mathrm{Mg} / \mathrm{m}^{3}\right)\end{array}$ & $\begin{array}{l}\text { Compaction ratio } \\
(\%)\end{array}$ & $\begin{array}{l}\text { Air void content } \\
\text { Vm }(\%)\end{array}$ \\
\hline MIX-R & 2.315 & 2.302 & 2.548 & 99.4 & 9.7 \\
MIX-1 & 2.312 & 2.301 & 2.548 & 99.5 & 9.7 \\
MIX-2 & 2.305 & 2.295 & 2.548 & 99.6 & 9.9 \\
MIX-3 & 2.32 & 2.318 & 2.548 & 99.9 & 9.0 \\
MIX-4 & 2.282 & 2.263 & 2.535 & 99.2 & 10.7 \\
MIX-5 & 2.299 & 2.282 & 2.540 & 99.3 & 10.1 \\
MIX-6 & 2.293 & 2.284 & 2.529 & 99.6 & 9.7 \\
\hline
\end{tabular}

Analysis of the results suggests that similar values of the compaction ratio and the air void content obtained for all the mixes confirm the same level of compression of the mineral constituents in the mixes. The resulting structure allows comparing the air void values and excluding the impact of the reduced load bearing capacity of the air voids. It has to be noted that all the mixes under consideration obtained the values lying within the limits defined by the requirements [3], [13] with respect to the air void content and the compaction ratio.

To confirm the lack of significant differences between the obtained results from the air void content $\left(\mathrm{V}_{\mathrm{m}}\right)$ tests, a oneway analysis of variance was conducted. The assumed level of significance was $\alpha=0.1$ [1]. The results of the analysis are shown in Table 5. 
Table 5. Impact significance evaluation of mixes (MIX) on $\mathrm{V}_{\mathrm{m}}$ of the recycled base

\begin{tabular}{ll}
\hline \multirow{2}{*}{ Variable } & Analysis of Variance \\
& Marked effects are significant at $\mathrm{p}<.10000$ \\
\hline \multirow{2}{*}{ Air void content $\left(\mathrm{V}_{\mathrm{m}}\right)$} & P-value \\
\hline
\end{tabular}

Analysis the significance evaluation implies that from the statistical point of view, in the group of mixes studied there are no significant differences between the means of air void content $\left(\mathrm{V}_{\mathrm{m}}\right)$. In addition, the $\mathrm{p}$-value $=0.999911$ is close to 1.0 , which means that there are no differences for the studied attribute.

The test program, defining the effect of the hydraulic binder type on the basic parameters of the cold recycled base mix with bitumen emulsion, was designed to determine:

- Absorption

- Indirect tensile strength $\mathrm{ITS}_{\mathrm{DRY}}$ at $25^{\circ} \mathrm{C}$

- Indirect tensile strength $\mathrm{ITS}_{40}{ }^{\circ} \mathrm{C}$ at $40^{\circ} \mathrm{C}$

- Indirect tensile strength $\mathrm{ITS}_{\mathrm{WET}}$ at $25^{\circ} \mathrm{C}$

- Resistance to water TSR

- Indirect tensile stiffness modulus IT-CY at $2{ }^{\circ} \mathrm{C}, 10^{\circ} \mathrm{C}$ and $20^{\circ} \mathrm{C}$

A one-way analysis of variance was used to evaluate the results. Owing to the fact that one of the necessary conditions for using the traditional one-way analysis of variance was not met due to a lack of normal distribution, a non-parametric method was employed, the Kruskal-Wallis one-way analysis of variance [25].

\subsection{Absorption}

The aim of the study was to evaluate the water absorption of the recycled base with bitumen emulsion. Absorption is a physical property defining the ability of a material to absorb water under standarized conditions. This parameter allows specifying the tightness of a given layer. Higher absorption reduces the migration of water into the recycled base structure. The results of the study are shown in Fig. 2.

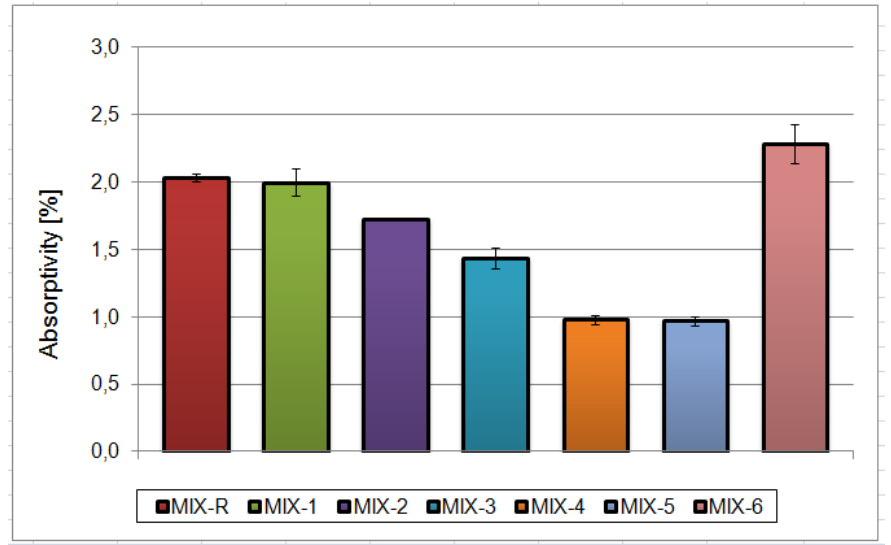

Fig. 2. Absorption of the recycled mixes (error bars denote the standard deviation values)

Analysis of the results leads to the conclusion that the mineral cement emulsion mixes are characterized by homogeneous susceptibility to water. The values obtained lie within the range from $1.0 \%$ in the case of MIX-4 and MIX-5 to $2.3 \%$ for MIX-6. All the mixes with the cement based binder have lower water susceptibility values than the mix with quicklime. An addition of cement to the binder enhances the hydration process in the water-binder environment and creates the structure that is compact enough to hinder the penetration of water. The mixes with the blend of cement and quicklime (MIX-4 and MIX-5) had the lowest means of susceptibility to water, i.e., $1.0 \%$. The combination of both binders may cause the coagulation of clay particles on the part of quicklime as their water absorption levels are high [26] and it may build a compact internal structure due to cement used.

Relative to the recommended mix, MIX-R, for making of which cement CEM I 32.5R was used, the absorption of mixes MIX-4 and MIX-5 was approximately $1.0 \%$ lower. The mix with the quicklime $(\mathrm{CaO})$ had this parameter higher by approximately $0.3 \%$.

The Kruskal-Wallis one-way analysis of variance [25] was used to evaluate the impact of the binder type on the change in the absorption values. The results from the analysis are presented in Table 6. 
Table 6. Impact significance evaluation of mixes (MIX) on $n_{w}$ of the recycled base in the Kruskal-Wallis test

\begin{tabular}{ll}
\hline & Multiple Comparisons p values (2-tailed); Nw \\
Depend.: & Independent (grouping) variable: Type \\
& Kruskal-Wallis test \\
\hline Absorption $\left(\mathrm{n}_{\mathrm{w}}\right)$ & P-value \\
\hline
\end{tabular}

The non-parametric Kruskal-Wallis test results [25] with $p$-value $=0.2488$ show that there is no evidence of significant differences among the mixes MIX-1 to MIX-7 at the assumed significance level of $\alpha=0.1$. The results of post-hoc analyses lead to the conclusion that no disparities among the absorption means can be suspected. At a slightly increased probability, $25 \%$, of rejecting the null hypothesis, there are differences within the group of the investigated mixes with respect to water absorption.

\subsection{Indirect tensile strength ITS}

The indirect tensile strength test is used to define the tensile stresses that occur in the recycled base. The test was performed on the Marshall samples with dimensions and diameters in accordance with PN-EN 12697-23:2004. Non-homogeneous surface of the samples due to unmolding does not affect the results, as proven by [27]. This test was run on three series of samples subjected to different conditioning processes. The first group contained the samples for indirect tensile strength testing at $25^{\circ} \mathrm{C}$. The samples in the second group were cured for 60 minutes at a temperature of $40{ }^{\circ} \mathrm{C}$. The temperature was used as a reference to the maximum temperature existing in the produced base course MCE [1]. The samples in the third group were cured in water for 24 hours at a temperature of $25^{\circ} \mathrm{C}$. The tests complied with the technical requirements laid down in [28]. The test results are summarised in Fig. 3.

(a)

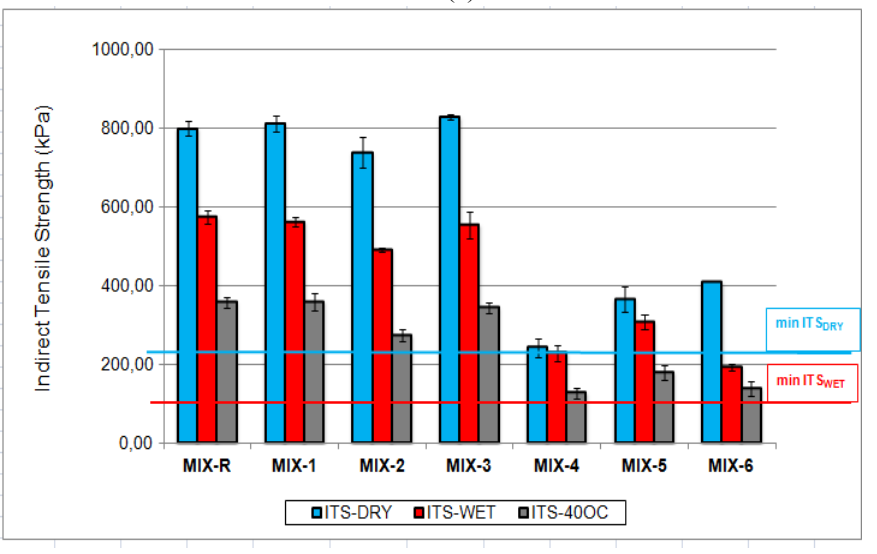

(b)

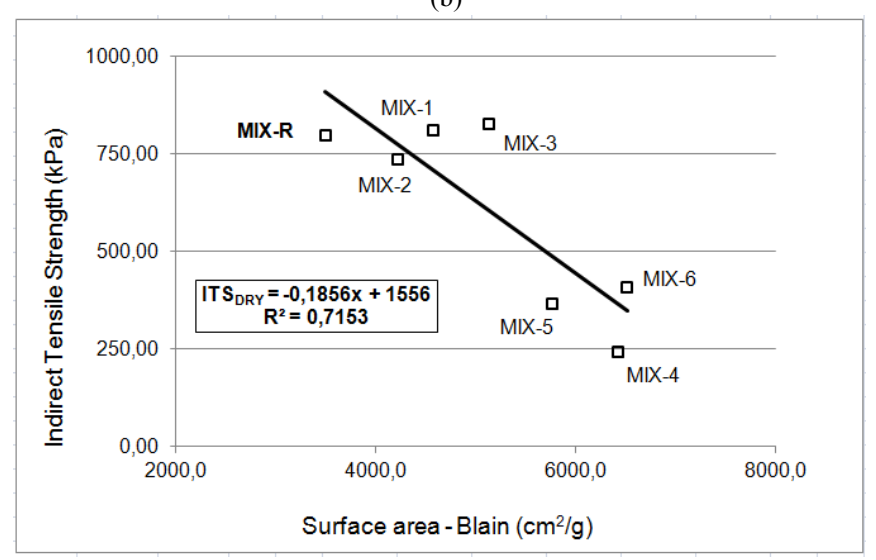

Fig. 3. Indirect tensile strength ITS (a) in relation to binder types (error bars denote the standard deviation) (b) in relation to the specific surface areas of binders

The highest ITS values were obtained for the mixes cured for seven days at a temperature of $25^{\circ} \mathrm{C}$. The tests reported in [7], [21, [29] led to the same conclusion. The guidelines [3], [13] require that the recycled base should have the parameters higher than the minimum parameters of $\mathrm{ITD}_{\mathrm{DRY}} \geq 225 \mathrm{kPa}$ and $\mathrm{ITS}_{\mathrm{WET}} \geq 100 \mathrm{kPa}$.

The evaluation of the results indicates that all the mixes MCE met the minimum indirect tensile strength criterion under air-dry conditions, ITSDRY. The maximum value was obtained by MIX-3 (828.95 kPa) with the binder composed on $50 \%$ CEM I $42.5 \mathrm{R}$ and $50 \%$ cement kiln dust (CKD). The high-class cement $42.5 \mathrm{R}$ ensures high strength at the initial phase of the test. But it has to be noted that in the case of the recycled base with cement, the behaviour of this layer should be characterised by flexibility. Otherwise, the layer being too stiff may cause damage in the form of reflected cracking.

The evaluation of the indirect tensile strength ITS $_{\text {WET }}$ following the curing in water shows that all the samples investigated reached the minimum required strength [13]. The mix with the lowest value of strength was MIX-6 $(192.76 \mathrm{kPa})$, containing quicklime as a binder. With regard to other binders, an addition of cement has a positive effect when the recycled base is subjected to an action of water. This phenomenon may be associated with cement hydration [12] in water during the curing process for the ITS $\mathrm{SWET}_{\mathrm{West}}$ t.

The indirect tensile strength test at an increased temperature of $40{ }^{\circ} \mathrm{C}$ was carried out to determine the ultimate strengths at maximum temperatures [1] inside the recycled base MCE. The reference criterion for the evaluation of the strength at increased temperature was $I R_{40}{ }^{\circ} \geq 100 \mathrm{kPa}$, in accordance with [13]. Based on this criterion, we have to conclude that all the mixes reached the required minimum indirect tensile strength value. The mixes MIX-R (CEM I 32.5R) and MIX-1 
(CEM II/B-V 32.5R) had the highest values of ITR $_{40}{ }^{\circ} \mathrm{C}, 360 \mathrm{kPa}$, containing the cement from a cement production plant. Similar result, $345.06 \mathrm{kPa}$, was recorded for MIX-3. This result suggests that an addition of $50 \%$ cement kiln dust (CKD) with the high-class Portland cement $42.5 \mathrm{R}$ does not reduce the strength at elevated temperatures.

Analysis of the indirect tensile strengths ITS $\mathrm{DRY}_{\mathrm{D}}$ and the specific surface area - Blaine presented in Fig. $3 \mathrm{~b}$ leads to the conclusion that the indirect tensile strength decreases with the increasing specific surface area - Blaine. Fluctuation in test results is $71.5 \%\left(\mathrm{R}^{2}=0.7153\right)$.

To evaluate the significance of impact of the binder type on the variation in the indirect tensile strengths $\left(\right.$ ITS $_{\mathrm{DRY}}$, ITS $_{\mathrm{WET}}$ and $\mathrm{ITS}_{40}{ }^{\circ} \mathrm{C}$ ), the one-way analysis of variance Kruskal-Wallis test was used [25]. The results of the tests are shown in Table 7.

Table 7. Impact significance evaluation of the mixes (MIX) on $\left(\mathrm{ITS}_{\mathrm{DRY}}\right.$, ITS $\mathrm{WET}_{\mathrm{W}}$ and $\left.\mathrm{ITS}_{40}{ }^{\circ} \mathrm{C}\right)$ of the recycled base - Kruskal-Wallis test

\begin{tabular}{ll}
\hline & Multiple Comparisons p values (2-tailed); Nw \\
Depend. & $\begin{array}{l}\text { Independent (grouping) variable: Type } \\
\text { Kruskal-Wallis test }\end{array}$ \\
\hline & P-value \\
\hline Indirect tensile strength $\left(\mathrm{ITS}_{\mathrm{DRY}}\right)$ & 0.2046 \\
Indirect tensile strength $\left(\mathrm{ITS}_{\mathrm{WET}}\right)$ & 0.3207 \\
Indirect tensile strength $\left(\mathrm{ITS}_{40} \mathrm{O}_{\mathrm{C}}\right)$ & 0.2694 \\
\hline
\end{tabular}

Based on the results of the non-parametric analysis of variance, we can conclude that at the assumed level of significance $\alpha=0.1$, there are no statistically significant differences among the mixes MIX-1 to MIX-7. The post-hocs testing of ITS $_{\mathrm{DRY}}$ parameters showed that between MIX-5 and MIX-6 the variation is greater than that among other mixes.

\subsection{Resistance to water TSR}

Water resistance testing was carried out in accordance with the guidelines specified in [28] and previously conducted by [7], [29]. The tests involved determining the decrease in the indirect tensile strength values after the process of curing the recycled base by soaking in water. The tensile strength retained (TSR $=$ Tensile Strength Ratio) is the indirect tensile strength ratio between the soaked and dry samples. The results of the water resistance tests for the samples of recycled base manufactured in deep cold recycling technique with bitumen emulsion in relation to the binder used are shown in Fig. 4.

(a)

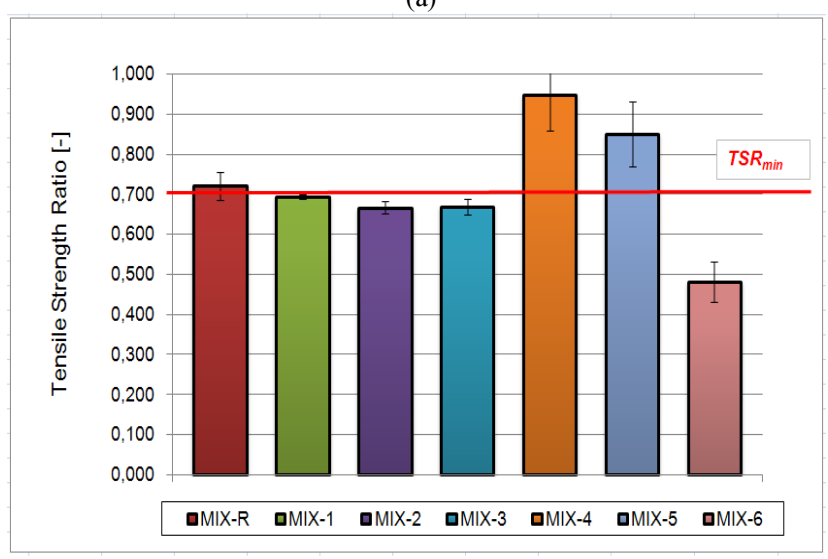

(b)

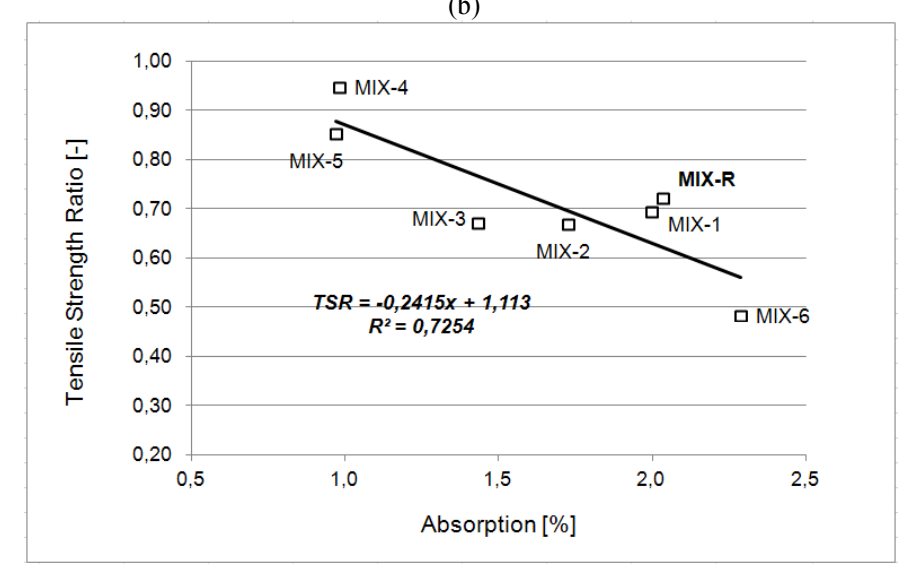

Fig. 4. Water resistance TSR (a) in relation to binder types (error bars denote the standard deviation) (b) in relation to absorption level ( $\left.\mathrm{n}_{\mathrm{w}}\right)$

Analysis of the results from the water resistance tests carried out on the recycled base MCE in terms of the binder type, presented in fig. 6(a) showed that regardless of the proportion used of the individual constituents, the mixes with cement and lime mixture based binders were resistant to the action of water, as required in [13]. The values of TSR for MIX-4 and MIX-5 were 0.95 and 0.85 , respectively. The reference mix MIX-R with the recommended in [3] cement CEM I 32.5R obtained the value which although satisfactory is lower than that of the lab-produced binder no. " 5 " and no. "6" (Table 3 ).

The lowest resistance to water was recorded for MIX-6 (TSR=0.48), with quicklime used as a binder. The lack of a proper amount of the silt clay part [26] prevented the proper bond between the lime and the mineral components.

Based on the results from the Kruskal-Wallis test [25], for the p-value $=0.3508$ and at the assumed level of significance of $\alpha=0.1$, we found that there is a likelihood that there is no difference between mixes from MIX-1 to MIX-6. The posthocs tests [25] revealed differences between MIX-4 and MIX-6 at the level of 0.595991.

To illustrate the relationship between the resistance to water and the absorption, Fig. 5 shows a correlation/ interdependence of these two characteristics. 
Pearson linear correlation results, as presented in fig. 6(b) [30], indicate the water resistance (TSR) relationship with absorption $\left(\mathrm{n}_{\mathrm{w}}\right)$ defined using a linear function. The variability in the characteristic interdependence results is $72.5 \%$ $\left(\mathrm{R}^{2}=0.7254\right)$.

\subsection{Stiffness modulus}

To evaluate the sensitivity of the recycled base with bitumen emulsion MCE against the binder type used, the IT-CY indirect tensile stiffness modulus method was used, as described in [31]. The tests were carried out at $2{ }^{\circ} \mathrm{C}, 10{ }^{\circ} \mathrm{C}$ and $20{ }^{\circ} \mathrm{C}$. The temperatures were chosen to relate to the base course performance in different seasons [32]. The stiffness modulus means obtained are presented in 6.

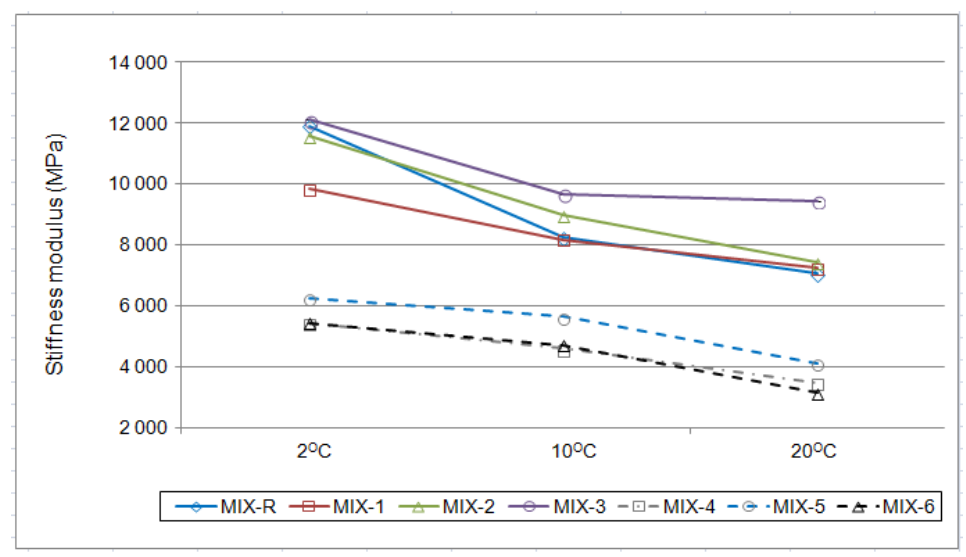

Fig. 6. Dependence of stiffness modulus on the recycled base temperature and binder types used

The spread of the test results shown in Fig. 6 is characteristic. Dashed lines denote the binders containing lime; the solid lines denote the cement based binders. There is an apparent boundary between the mixes. The minimum modulus value at $20{ }^{\circ} \mathrm{C}$ for binders with cement is twice as large as the one for the binders with lime. The transfer of the values obtained to real conditions of the recycling technology will prevent the layer made with the mix containing the binder with quicklime from shrinkage cracking while setting. According to the requirements [28] for the recycled mixes (a blend of reclaimed asphalt and crushed stone aggregate), the stiffness modulus at $25^{\circ} \mathrm{C}$ should fit the range from $2500 \mathrm{MPa}$ to $4000 \mathrm{MPa}$.

Thus the recycled base courses with binders based on cement have stiffness values much higher than those specified in the requirements.

To evaluate the test results considering the binder types used in the recycled base mix with binder emulsion MCE, the one-way analysis of variance ANOVA [25] was used. Table 8 illustrates the result of the analysis 8.

Table 8. Impact significance evaluation of the mixes (MIX) on $\mathrm{V}_{\mathrm{m}}$ of the recycled base.

\begin{tabular}{ll}
\hline Variable & $\begin{array}{l}\text { Analysis of Variance } \\
\text { Marked effects are significant at } \mathrm{p}<0,10000\end{array}$ \\
\hline & P-value \\
\hline Stiffness modulus $\left(\mathrm{S}_{\mathrm{m}}\right) \mathrm{w}+20^{\circ} \mathrm{C}$ & 0.09529 \\
Stiffness modulus $\left(\mathrm{S}_{\mathrm{m}}\right) \mathrm{w}+10^{\circ} \mathrm{C}$ & 0.04104 \\
Stiffness modulus $\left(\mathrm{S}_{\mathrm{m}}\right) \mathrm{w}+2{ }^{\circ} \mathrm{C}$ & 0.09854 \\
\hline
\end{tabular}

The p-values obtained in the tests for the types of binders used in relation to the recycled base characteristics $\left(\mathrm{S}_{\mathrm{m}+20} \mathrm{O}_{\mathrm{C}}\right.$, $\mathrm{S}_{\mathrm{m}+10{ }^{\circ} \mathrm{C}}$ and $\mathrm{S}_{\mathrm{m}+2{ }^{\circ} \mathrm{C}}$ ) lead to the conclusion that there are at least two groups that vary in a statistically significant way assuming the significance level to be $\alpha=0.1$, which provides evidence for disparities in the impact of the binder used on the stiffness modulus values obtained.

\section{Conclusions}

The following conclusions can be drawn from the present study of the recycled base with bitumen emulsion considered in terms the binder type:

- The type of the binder used in the recycled base mineral cement emulsion mix at $2.5 \%$ has no effect on the air void content $\mathrm{V}_{\mathrm{m}}$;

- Mixes produced with the blends of $25 \%$ cement and $75 \%$ lime as well as those with $50 \%$ cement and $50 \%$ lime have lower absorption values compared with the reference mix; 
- The results obtained from the indirect tensile strength tests, regardless of the method used, indicate that the mineral cement emulsion mixes with cement based binders (MIX-R, MIX-1 and MIX-2) have strength values two times higher than the mixes whose composition contains a blend of cement and lime (MIX-4 do MIX-5) and 100\% quicklime MIX-6;

- From the water resistance tests it follows that only MIX-R, MIX-4 and MIX-5 are resistant to water;

- Correlation of absorption $\left(\mathrm{n}_{\mathrm{w}}\right)$ of the recycled base MCE as well as the decrease in water resistance (TSR) has been explained in $72.5 \%$ using a linear function;

- Mixes with cement base binders (MIX-R to MIX-3) have too high stiffness modulus values;

- An increase in the specific surface area - Blaine causes a decrease in the indirect tensile strength;

- The mixes that contain binders resulting from the combination of cement and quicklime have better parameters compared with the reference mix with the recommended cement type CEM I 32.5R.

\section{References}

[1] Kukiełka, J.; Kukiełka, J.; 2009. Recykling nawierzchni asfaltowych w Polsce - warunki i technologie. Międzynarodowa Konferencja NaukowoTechniczna. Ochrona Środowiska i Estetyka a Rozwój Infrastruktury Drogowej. Kazimierz Dolny, 328-340.

[2] Iwański, M. 2006. Podbudowa z asfaltem spinionym. Drogownictwo 3/2006 97-106.

[3] IBDiM 1999 Warunki techniczne wykonywania warstw podbudowy z mieszanki mineralno-cementowo-emulsyjnej (MCE), Zeszyt 61, IBDiM [Road and Bridge Research Institute], Warszawa, p. 44. (in Polish)

[4] Niazi, Y.; Jalili, M. 2009. Effect of Portland cement and lime additives on properties of cold in-place recycled mixtures with asphalt emulsion, Construction and Building Materials 23: 1338-1343. http://dx.doi.org/10.1016/j.conbuildmat.2008.07.020

[5] Isola, M.; Betti, G.; Marradi, A.; Tebaldi, G. 2013. Evaluation of cement treated mixtures with high percentage of reclaimed asphalt pavement, Construction and Building Materials 48: 238-247. http://dx.doi.org/10.1016/j.conbuildmat.2013.06.042

[6] Modarres, A.; Neja, F. M.; Kavussi, A.; Hassani, A.; Shabanzadeh, E. 2011. A parametric study on the laboratory fatigue characteristics of recycled mixes, Construction and Building Materials 25: 2085-2093. http://dx.doi.org/10.1016/j.conbuildmat.2010.11.030

[7] Iwański, M.; Chomicz-Kowalska, A. 2013. Laboratory Study on Mechanical Parameters of Foamed Bitumen Mixtures in the Cold Recycling Technology, in 11th International Conference on Modern Building Materials, Structures and Techniques, MBMST 2013, Procedia Engineering $57: 433-442$.

[8] Iwański, M.; Chomicz-Kowalska, A. 2011. The effects of using foamed bitumen and bitumen emulsion in the cold recycling technology, in 8th International Conference. Environmental Engineering. May 19-20, 2011, Vilnius, Lithuania, 1089-1096.

[9] Mallick, R. B.; Grant Hendrix, Jr. 2004. Use of foamed asphalt in recycling incinerator ash for construction of stabilized base course, Resources, Conservation and Recycling 42: 239-248. http://dx. doi.org/10.1016/j.resconrec.2004.04.007

[10] Dz.U.1999.43.430 Rozporządzenie Ministra Transportu i Gospodarki Morskiej z dnia 2 marca 1999 r. w sprawie warunków technicznych, jakim powinny odpowiadać drogi publiczne i ich usytuowanie.

[11] PN-EN 13808:2013-10E. 2013. Asfalty i lepiszcza asfaltowe - Zasady klasyfikacji kationowych emulsji asfaltowych (in Polish)

[12] Neville, A. M. 2012. Wtaściwości Betonu. Stowarzyszenie Producentów Cementu. 900 p. ISBN 83-913000-0-5

[13] Asphalt Academy, 2009. Technical Guideline: Bitumen Stabilized Materials, A Guideline for the Design and Construction of Bitumen Emulsion and Foamed Bitumen Stabilized Materials, Technical Guideline 2 (TG2), Asphalt Academy, Second Edition, Pretoria, South Africa, May 2009.

[14] Iwański, M.; Buczyński, P. 2012. Wpływ pyłów mineralnych na moduł sztywności podbudowy z asfaltem spienionym, Zeszyt Naukowy Politechniki Rzeszowskiej Budowwnictwo i Inżynieriia Środowiska zeszyt 59(3): 221-228.

[15] Bożym, M. 2011. Alternatywne metody wykorzystania pyłów z pieców wapienniczych i cementowych, ze szczególnym uwzględnieniem gospodarki osadowej. Instytut Ceramiki i Materiałów Budowlanych, Scientific Worksof Instytut of Ceramics and Building Materials 8: 59-68.

[16] Strydom, C. A.; Roode, Q. I.; Potgieter, J. H. 1996. Thermogravimetric and X-ray powder diffractio analysis of precipitator dust from a rotating lime kiln, Cement Concrete Research 26: 1269-1276.

[17] Mackie, A.; Boilard, S.; Walsh, M. E.; Lake, C. B. 2010. Physicochemical characterization of cement kiln dust for potential reuse in acidic wastewater treatment, Journal of Hazardous Materials 173: 283-291. http://dx.doi.org/10.1016/j.jhazmat.2009.08.081

[18] Miller, G. A. U.; Azad, S. 2000. Influence of soil type on stabilization with cement kiln dust, Construction and Building Materials 14: 89-97. http://dx.doi.org/10.1016/S0950-0618(00)00007-6

[19] Sreekrishnavilasam, A.; Rahardja, S.; Kmetz, R.; Santagata, M. 2007. Soil treatment using fresh and landfilled cement kiln dust, Construction and Building Materials 21: 318-327. http://dx.doi.org/10.1016/j.conbuildmat.2005.08.015

[20] Osiecka, E. 2005. Materialy budowlane. Spoiwa mineralne - kruszywa. OWPW. 118 p. ISBN: 83-7207-536-0

[21] Pradyumna, T. A.; Mittal, A.; Jain, P. K. 2013. Characterization of Reclaimed Asphalt Pavement (RAP) for Use in Bituminous Road Construction, in Procedia - Social and Behavioral Sciences 104:1149-1157.

[22] PN-EN 13286-2:2010E. Mieszanki niezwiązane i związane hydraulicznie - Część 2: Metody badań laboratoryjnych gęstości na sucho i zawartości wody - Zagęszczanie metodą Proktora. (In Polish)

[23] PN-EN 12697-5:2010E. Mieszanki mineralno-asfaltowe - Metody badań mieszanek mineralno-asfaltowych na gorąco - Część 5: Oznaczanie gęstości. (In Polish)

[24] PN-EN 12697-6:2012E. Mieszanki mineralno-asfaltowe - Metody badań mieszanek mineralno-asfaltowych na gorąco -- Część 6: Oznaczanie gęstości objętościowej próbek mieszanki mineralno-asfaltowej. (In Polish)

[25] Montgomery, D. G. 2001. Design and Analysis of Experiments, 5th Edition, John Wiley and Sons, 607 p.

[26] Wiłun, Z. 2013. Zarys Geotechniki. Wydawnikctwo Komunikacji I Łączności WKŁ. 724 p. ISBN 978-83-206-1914-0

[27] Tayfur, S.; Ozen, H.; Aksoy, A. 2007. Investigation of rutting performance of asphalt mixtures containing polymer modifiers, Constr Build Mater 21: 328-337. http://dx.doi.org/10.1016/j.conbuildmat.2005.08.014

[28] Wirtgen Group, Cold Recycling Technology.1th edition, Wirtgen GmbH, Windhagen, Germany, 2012

[29] Kavussi, A.; Modorres, A. 2010. A model for resilient modulus determination of recycled mixes with bitumen emulsion and cement from ITS testing results, Construction and Building Materials 24: 2252-2259. http://dx.doi.org/10.1016/j.conbuildmat.2010.04.031

[30] Wasilewska, E. 2011. Statystyka opisowa od podstaw Podręcznik z zadaniami. SGGW. $424 \mathrm{~s}$.

[31] PN-EN 12697-26 Mieszanki mineralno-asfaltowe - Metody badań mieszanek mineralno-asfaltowych na gorąco. Część 26: Sztywność. Załącznik C (In Polish)

[32] IBDiM. 2001. Katalog Wzmocnień i Remontów Nawierzchni Podatnych i Półsztywnych. Warszawa. 225 p. 